\title{
PRAEFATIO
}

aetatibus definiendis ceterisque rebus palaeographicis, in quibus cedebat nemini, egregie adiuvabat, quominus hoc loco gratias debitas agerem, prohibuit fatum nobis amicis eius superstitibus scientiaeque iniquissimum.

Scr. Hauniae mense Aprili MDCCCLXXXIII

\section{L. Heiberg}

\section{ADDITAMENTVM PRAEFATIONIS}

Nemo ex viris antiquae geometriae peritis est quin putet nova editione Euclidis Elementorum in praesenti opus esse. exemplaria enim praeclarae editionis Heibergianae iamdudum divendita sunt, studia autem ad Elementa pertinentia nostra aetate admodum increverunt.

Qua de re cum a bibliopola honestissimo, hortatu Instituti scientiae antiquitatis Graecoromanae, quod auctoritate Academiae Scientiarum Germanicae Berolinensis constitutum est, invitatus essem, ut novam Euclidis Elementorum editionem curarem, gratissimo animo hoc negotium suscepi. nam multos studiosos scientiae mathematicae, qui Graece sciunt, Euclidianum textum desiderare cognovi.

Valde autem mihi consilium bibliopolae honestissimi placuit, qui mihi suasit, ut translationem Latinam qua Heiberg editionem suam instruxerat omitterem, quo nova editio brevior in lucem prodiret. patet enim linguae Graecae peritos Latina translatione non nimis egere. quae cum ita sint, ratio novae editionis, ita ut infra indicatur, ordinata est:

Textui primi voluminis praemittenda, quae de Elementis et de vita Euclidis et de principiis primordiisque geometriae tradita sunt, existimavi. annexui continuo tres indices. tertio loco conspectum, in quo praestantissimae Euclidis Elementorum editiones memorantur, adiunxi. 


\section{PRAEFATIO}

Quod ad textum attinet Heibergianae editionis vestigia ingredi statui. nam inter omnes viros doctos Heiberg optime de Euclidis Elementis meritum esse constat. neque enim post obitum eius codices novi, praeter quos ille inspexerat, collati sunt, neque seges papyrorum nobis novas lectiones praebuit. ipse autem editionis Heibergianae perfectionem absolutionemque perspexi, cum meam Euclidis Elementorum editionem, quae annis 1952-1957 Athenis impressa est, absolverem.

Inferiorem paginarum marginem hoc modo disposui: notas ab Heiberg textui suae translationis Latinae insertas in superiorem locum transtuli, primo et ultimo Graeco vocabulo sententiae ad quam pertineant designato numeroque versus memorato. ibidem etiam testimonia ad eandem translationem spectantia eodem modo collocavi. adiunxi deinde reliqua testimonia ad propositiones spectantia, quae numeris Graecis significavi, et varias lectiones ex editione Heibergiana.

Varia additamenta in calce uniuscuiusque voluminis collocanda censui.

Restat, ut gratias maximas agam Iohannes Irmscher, quod non solum in hac editione curanda consilio me adiuvit, verum etiam auctor fuit, ut editio ipsa a bibliopola honestissimo mihi committeretur.

Scribebam Athenis mense Septembri MCMLXI

E. S. Stamatis 